Key Words:

Sulfur, molybdenum, solubility, high level waste glass

Retention:

Permanent

\title{
COMBINED RETENTION OF MOLYBDENUM AND SULFUR IN SIMULATED HIGH LEVEL WASTE GLASS
}

\author{
W.T. Shoulders \\ K.M. Fox
}

SEPTEMBER 2009

Savannah River National Laboratory

Savannah River Nuclear Solutions

Aiken. SC 29808

Prepared for the U.S. Department of Energy Under Contract Number DE-AC09-08SR22470 


\section{DISCLAIMER}

This work was prepared under an agreement with and funded by the U.S. Government. Neither the U. S. Government or its employees, nor any of its contractors, subcontractors or their employees, makes any express or implied:

1. warranty or assumes any legal liability for the accuracy, completeness, or for the use or results of such use of any information, product, or process disclosed; or

2. representation that such use or results of such use would not infringe privately owned rights; or

3. endorsement or recommendation of any specifically identified commercial product, process, or service.

Any views and opinions of authors expressed in this work do not necessarily state or reflect those of the United States Government, or its contractors, or subcontractors.

Printed in the United States of America

Prepared for

U.S. Department of Energy 
Key Words:

Sulfur, molybdenum, solubility, high level waste glass

Retention:

Permanent

\title{
COMBINED RETENTION OF MOLYBDENUM AND SULFUR IN
} SIMULATED HIGH LEVEL WASTE GLASS

\author{
W.T. Shoulders \\ K.M. Fox
}

SEPTEMBER 2009

Savannah River National Laboratory

Savannah River Nuclear Solutions

Savannah River Site

Aiken, SC 29808 
SRNL-STI-2009-00569, REVISION 0

\section{REVIEWS AND APPROVALS}

W.T. Shoulders, Co-author, Process Technology Programs

Date

K.M. Fox, Co-author, Process Technology Programs

Date

D.K. Peeler, Peer Reviewer, Process Technology Programs

Date

C. C. Herman, Manager, Process Technology Programs

Date

S. L. Marra, Manager,

Date

Environmental \& Chemical Process Technology Research Programs

- ii - 


\section{TABLE OF CONTENTS}

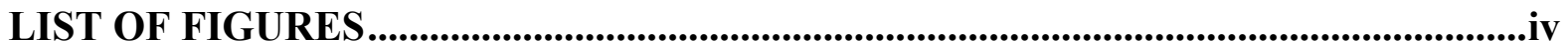

LIST OF TABLES.....................................................................................................................

LIST OF ACRONYMS .......................................................................................................................

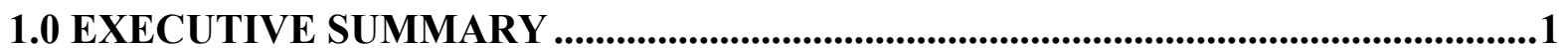

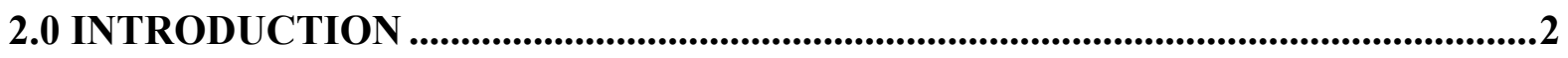

3.0 EXPERIMENTAL PROCEDURE ....................................................................................3

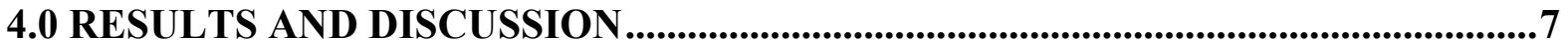

5.0 SUMMARY .....................................................................................................................12

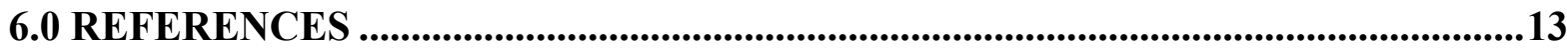

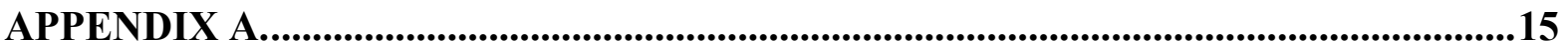




\section{LIST OF FIGURES}

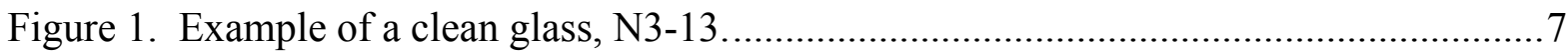

Figure 2. Example of tan residue on glass N3-23 ............................................................

Figure 3. Preliminary model for sulfur and molybdenum retention in the SB6 - Frit 418

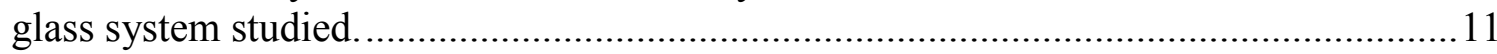

\section{LIST OF TABLES}

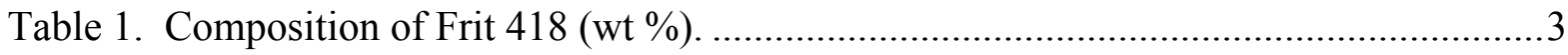

Table 2. Target Compositions of Glasses N3-01 through N3-12 (wt \%) ................................

Table 3. Target Compositions for Glasses N3-13 through N3-24 (wt \%) ...............................

Table 4. Visual observations of glasses after cooling in crucibles.......................................... 8

Table 5. Target and measured concentrations of $\mathrm{SO}_{4}{ }^{2-}$ and $\mathrm{MoO}_{3}$ in the study glasses...........9

Table 6. Concentrations of elements measured in the wash water samples...........................10 


\section{LIST OF ACRONYMS}

CCC

DI water

DWPF

ICP-AES

PCCS

PSAL

SB4

SB6

SRNL

SRS canister centerline cooled

de-ionized water

Defense Waste Processing Facility

Inductively Coupled Plasma - Atomic Emission Spectroscopy

Product Composition Control System

Process Science Analytical Laboratory

Sludge Batch 4

Sludge Batch 5

Savannah River National Laboratory

Savannah River Site 


\subsection{EXECUTIVE SUMMARY}

This study was undertaken to investigate the effect of elevated sulfate and molybdenum concentrations in nuclear waste glasses. A matrix of 24 glasses was developed and the glasses were tested for acceptability based on visual observations, canister centerline-cooled heat treatments, and chemical composition analysis. Results from the chemical analysis of the rinse water from each sample were used to confirm the presence of $\mathrm{SO}_{4}{ }^{2-}$ and $\mathrm{MoO}_{3}$ on the surface of glasses as well as other components which might form water soluble compounds with the excess sulfur and molybdenum.

A simple, linear model was developed to show acceptable concentrations of $\mathrm{SO}_{4}{ }^{2-}$ and $\mathrm{MoO}_{3}$ in an example waste glass composition. This model was constructed for scoping studies only and is not ready for implementation in support of actual waste vitrification. Several other factors must be considered in determining the limits of sulfate and molybdenum concentrations in the waste vitrification process, including but not limited to, impacts on refractory and melter component corrosion, effects on the melter off-gas system, and impacts on the chemical durability and crystallization of the glass product. 


\subsection{INTRODUCTION}

Composition projections of Sludge Batch 6 (SB6), to be vitrified at the Defense Waste Processing Facility (DWPF), predict relatively high concentrations of sulfate $\left(\mathrm{SO}_{4}{ }^{2-}\right)$ in the sludge. ${ }^{1}$ Increased concentrations of molybdenum oxide $\left(\mathrm{MoO}_{3}\right)$ are an issue at other waste vitrification plants, such as Sellafield in the U.K. Elevated sulfate concentrations in particular raise several issues with the processing of sludge and frit mixtures and performance of the final glass product. Should a need arise to vitrify a waste stream containing both sulfur and molybdenum, an understanding of the combined solubility of these components and the potential for formation of insoluble molybdenum sulfates would need to be better understood.

A high sulfate concentration is a concern as it can lead to the formation of sulfate inclusions in the glass and the formation of a molten, sulfate-rich phase atop the melt pool. The presence of this low viscosity melt phase on the surface of the melt pool increases corrosion rates of the materials of construction, including the off-gas system and refractories (primarily at the melt line), as well as melter top head components (e.g., thermowells, level dip tube and upper electrodes). The molten salt layer is purported to enhance the potential for steam explosions in waste glass melters that are slurry fed. $^{2}$ In addition, there is the potential for undesirable current paths to develop that could deplete energy delivered to the melter due to the high electrical conductivity of the molten salt layer. For example, the DWPF avoids these issues through the implementation of a sulfate concentration limit, originally set in the Product Composition Control System (PCCS) at $0.4 \mathrm{wt} \% \mathrm{SO}_{4}{ }^{2-}$ in glass, ${ }^{3-5}$ and later $0.6 \mathrm{wt} \% \mathrm{SO}_{4}{ }^{2-}$ in glass for Sludge Batch 4 (SB4). ${ }^{6}$

As another example, waste containing relatively high molybdenum concentrations has been processed at the Sellafield, U.K. vitrification plant. Studies in support of Sellafield have shown that molybdenum accelerated corrosion of melters in its liquid state and was highly soluble in water as a solid. ${ }^{7}$ When the solubility limit in glass is exceeded, Mo ions in various oxidation states have the capability of bonding to radioactive ions in a solid salt on the surface of a glass.

This work is designed as a scoping study of the combined solubility limits of $\mathrm{SO}_{4}{ }^{2-}$ and $\mathrm{MoO}_{3}$ in a simulated high level waste glass. The goal is to produce a plot of $\mathrm{SO}_{4}{ }^{2-}$ retention versus $\mathrm{MoO}_{3}$ retention that can be used as a simple model to predict the retention of these components, using SB6 as a model system. It should be noted that the retention limits of $\mathrm{SO}_{4}{ }^{2-}$ and $\mathrm{MoO}_{3}$ are very likely dependent on the overall glass composition; therefore the results of this study may not be applicable to other waste compositions. The data presented in this report are not sufficient to provide guidelines for actual waste vitrification, but merely insight into the combined retention of these components in a borosilicate glass. 
SRNL-STI-2009-00569, REVISION 0

\subsection{EXPERIMENTAL PROCEDURE}

\subsection{GLASS MATRIX SELECTION}

Initially, 12 glass compositions were designed for this study. The sludge composition chosen as an example for this study originated from a March 2009 SB6 projection. ${ }^{a}$ Sulfate and the radioactive components $\left(\mathrm{ThO}_{2}\right.$ and $\left.\mathrm{U}_{3} \mathrm{O}_{8}\right)$ were removed from the projection with the remaining components normalized to $100 \mathrm{wt} \%$. Frit 418 (Table 1) was selected as a likely candidate for vitrification of SB6. A waste loading of $35 \%$ was arbitrarily chosen based on processing of previous sludge batches at the DWPF. A base glass composition, designated N3-01 was calculated using these conditions. Finally, $\mathrm{SO}_{4}{ }^{2-}$ and $\mathrm{MoO}_{3}$ were added to the base glass composition at fixed concentrations as described below, with the glass compositions then being normalized to $100 \mathrm{wt} \%$.

Table 1. Composition of Frit 418 (wt \%).

\begin{tabular}{|c|c|c|c||}
\hline $\mathbf{B}_{\mathbf{2}} \mathbf{O}_{\mathbf{3}}$ & $\mathbf{L i}_{\mathbf{2}} \mathbf{O}$ & $\mathbf{N a}_{\mathbf{2}} \mathbf{O}$ & $\mathbf{S i O}_{\mathbf{2}}$ \\
\hline 8.0 & 8.0 & 8.0 & 76.0 \\
\hline
\end{tabular}

The first 12 test glass compositions were designed around the current sulfate solubility limit. Sulfate concentrations were chosen at, below, and above the concentration limit of $0.6 \mathrm{wt} \%$ set for SB5, ${ }^{9}$ specifically $0.0,0.6$ and $1.2 \mathrm{wt} \% \mathrm{SO}_{4}{ }^{2-10} \cdot{ }^{10}$ Molybdenum was added at concentrations of $0,2,4$ and 6 wt $\% \mathrm{MoO}_{3}$. The resulting glass compositions are given in Table 2.

After the first twelve glasses were melted and observed, twelve new compositions were devised to more closely determine the $\mathrm{SO}_{4}{ }^{2-}$ to $\mathrm{MoO}_{3}$ solubility relationship. A more narrow range of molybdenum concentrations was used, covering 1.0 to $3.5 \mathrm{wt} \% \mathrm{MoO}_{3}$ in $0.5 \mathrm{wt} \%$ increments. These were combined with sulfate concentrations of $0.0,0.2,0.4,0.5$ and $0.6 \mathrm{wt} \% \mathrm{SO}_{4}{ }^{2-}$, as shown in Table 3.

\footnotetext{
a An SB6 composition projection was received from the Liquid Waste Organization Planning Group via email in March 2009 , and was closely based on the SB6 Variation 8 composition suggested by SRNL. ${ }^{8}$
} 
SRNL-STI-2009-00569, REVISION 0

Table 2. Target Compositions of Glasses N3-01 through N3-12 (wt \%)

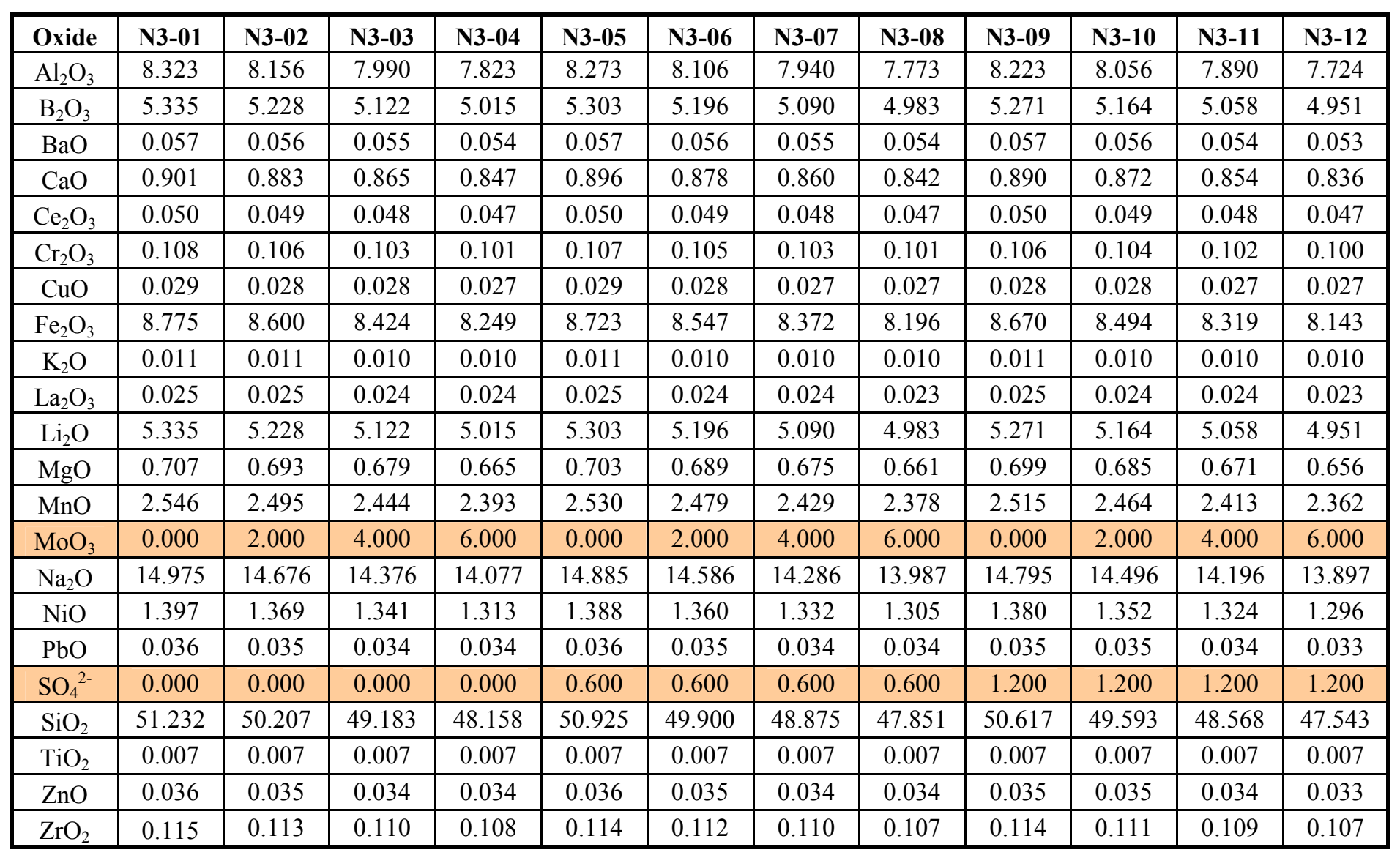


Table 3. Target Compositions for Glasses N3-13 through N3-24 (wt \%).

\begin{tabular}{|c|c|c|c|c|c|c|c|c|c|c|c|c|}
\hline " Oxide & N3-13 & N3-14 & N3-15 & N3-16 & N3-17 & N3-18 & N3-19 & N3-20 & N3-21 & N3-22 & N3-23 & N3-24 \\
\hline $\mathrm{Al}_{2} \mathrm{O}_{3}$ & 8.223 & 8.206 & 8.190 & 8.181 & 8.165 & 8.156 & 8.140 & 8.123 & 8.115 & 8.115 & 8.073 & 8.031 \\
\hline $\mathrm{B}_{2} \mathrm{O}_{3}$ & 5.271 & 5.260 & 5.250 & 5.244 & 5.234 & 5.228 & 5.218 & 5.207 & 5.202 & 5.202 & 5.175 & 5.148 \\
\hline $\mathrm{BaO}$ & 0.057 & 0.057 & 0.057 & 0.056 & 0.056 & 0.056 & 0.056 & 0.056 & 0.056 & 0.056 & 0.056 & 0.055 \\
\hline $\mathrm{CaO}$ & 0.890 & 0.889 & 0.887 & 0.886 & 0.884 & 0.883 & 0.881 & 0.880 & 0.879 & 0.879 & 0.874 & 0.870 \\
\hline $\mathrm{Ce}_{2} \mathrm{O}_{3}$ & 0.050 & 0.050 & 0.049 & 0.049 & 0.049 & 0.049 & 0.049 & 0.049 & 0.049 & 0.049 & 0.049 & 0.049 \\
\hline $\mathrm{Cr}_{2} \mathrm{O}_{3}$ & 0.106 & 0.106 & 0.106 & 0.106 & 0.106 & 0.106 & 0.105 & 0.105 & 0.105 & 0.105 & 0.104 & 0.104 \\
\hline $\mathrm{CuO}$ & 0.028 & 0.028 & 0.028 & 0.028 & 0.028 & 0.028 & 0.028 & 0.028 & 0.028 & 0.028 & 0.028 & 0.028 \\
\hline $\mathrm{Fe}_{2} \mathrm{O}_{3}$ & 8.670 & 8.652 & 8.635 & 8.626 & 8.608 & 8.600 & 8.582 & 8.565 & 8.556 & 8.556 & 8.512 & 8.468 \\
\hline $\mathrm{K}_{2} \mathrm{O}$ & 0.011 & 0.011 & 0.011 & 0.011 & 0.011 & 0.011 & 0.011 & 0.011 & 0.011 & 0.011 & 0.010 & 0.010 \\
\hline $\mathrm{La}_{2} \mathrm{O}_{3}$ & 0.025 & 0.025 & 0.025 & 0.025 & 0.025 & 0.025 & 0.025 & 0.025 & 0.025 & 0.025 & 0.024 & 0.024 \\
\hline $\mathrm{Li}_{2} \mathrm{O}$ & 5.271 & 5.260 & 5.250 & 5.244 & 5.234 & 5.228 & 5.218 & 5.207 & 5.202 & 5.202 & 5.175 & 5.148 \\
\hline $\mathrm{MgO}$ & 0.699 & 0.697 & 0.696 & 0.695 & 0.694 & 0.693 & 0.692 & 0.690 & 0.690 & 0.690 & 0.686 & 0.683 \\
\hline $\mathrm{MnO}$ & 2.515 & 2.510 & 2.505 & 2.502 & 2.497 & 2.495 & 2.490 & 2.485 & 2.482 & 2.482 & 2.469 & 2.457 \\
\hline $\mathrm{MoO}_{3}$ & 1.000 & 1.000 & 1.000 & 1.500 & 1.500 & 1.500 & 2.000 & 2.000 & 2.000 & 2.500 & 3.000 & 3.500 \\
\hline $\mathrm{Na}_{2} \mathrm{O}$ & 14.795 & 14.765 & 14.735 & 14.720 & 14.690 & 14.676 & 14.646 & 14.616 & 14.601 & 14.601 & 14.526 & 14.451 \\
\hline $\mathrm{NiO}$ & 1.380 & 1.377 & 1.374 & 1.373 & 1.370 & 1.369 & 1.366 & 1.363 & 1.362 & 1.362 & 1.355 & 1.348 \\
\hline $\mathrm{PbO}$ & 0.035 & 0.035 & 0.035 & 0.035 & 0.035 & 0.035 & 0.035 & 0.035 & 0.035 & 0.035 & 0.035 & 0.035 \\
\hline $\mathrm{SO}_{4}^{2-}$ & 0.200 & 0.400 & 0.600 & 0.200 & 0.400 & 0.500 & 0.200 & 0.400 & 0.500 & 0.000 & 0.000 & 0.000 \\
\hline $\mathrm{SiO}_{2}$ & 50.617 & 50.515 & 50.412 & 50.361 & 50.259 & 50.207 & 50.105 & 50.002 & 49.951 & 49.951 & 49.695 & 49.439 \\
\hline $\mathrm{TiO}_{2}$ & 0.007 & 0.007 & 0.007 & 0.007 & 0.007 & 0.007 & 0.007 & 0.007 & 0.007 & 0.007 & 0.007 & 0.007 \\
\hline $\mathrm{ZnO}$ & 0.035 & 0.035 & 0.035 & 0.035 & 0.035 & 0.035 & 0.035 & 0.035 & 0.035 & 0.035 & 0.035 & 0.035 \\
\hline $\mathrm{ZrO}_{2}$ & 0.114 & 0.113 & 0.113 & 0.113 & 0.113 & 0.113 & 0.112 & 0.112 & 0.112 & 0.112 & 0.111 & 0.111 \\
\hline
\end{tabular}




\subsection{GLASS FABRICATION}

Each sulfate and molybdenum doped glass was prepared from the proper proportions of reagent-grade metal oxides, carbonates, boric acid, and salts in $150 \mathrm{~g}$ batches. The raw materials were thoroughly mixed and placed into a $95 \% \mathrm{Pt} / 5 \% \mathrm{Au}, 250 \mathrm{~mL}$ crucible and covered with a platinum/gold lid. The crucibles were placed into a high-temperature furnace at the melt temperature of $1150{ }^{\circ} \mathrm{C}$. After an isothermal hold at $1150{ }^{\circ} \mathrm{C}$ for $1.0 \mathrm{~h}$, the crucibles were removed from the furnace and placed on a steel plate to cool. Visual observations of the cooled glasses and of the crucibles after removing the glass were documented. Rinse tests and chemical composition determinations were completed for each of the glasses as described below.

\subsection{GLASS COMPOSITION ANALYSIS}

Rinse tests for N3-01 through N3-24 were prepared by pouring $10 \mathrm{~mL}$ of de-ionized water (DI water) into the crucible then sloshing and pouring into a labeled scintillation vial. The samples were submitted to the Process Science Analytical Laboratory (PSAL) for analysis of the concentration of dissolved solids, including $\mathrm{Ca}, \mathrm{Cr}, \mathrm{Li}, \mathrm{Mo}, \mathrm{Na}$, and $\mathrm{S}$. In addition, samples of about $5 \mathrm{~g}$ of each glass were submitted to PSAL for chemical composition analysis. The glass samples were dissolved using a lithium metaborate fusion and the resulting liquids were analyzed using Inductively Coupled Plasma - Atomic Emission Spectroscopy (ICP-AES).

\subsection{CANISTER CENTERLINE COOLING (CCC)}

Samples of glasses N3-01 through N3-12 were heat treated to simulate slow cooling along the centerline of a DWPF canister to visually identify any crystallization that may occur during more kinetically favorable, slow cooling conditions. About $30 \mathrm{~g}$ of each glass was placed in a $100 \mathrm{~mL} 95 \%$ $\mathrm{Pt} / 5 \% \mathrm{Au}$ crucible. All twelve crucibles were placed in a furnace at $1150{ }^{\circ} \mathrm{C}$. A program was then started to slowly cool the furnace following a schedule developed based on actual cooling data of an instrumented canister. ${ }^{11}$ The crucibles were removed from the furnace after the program had finished. Visual observations were recorded. 


\subsection{RESULTS AND DISCUSSION}

\subsection{VISUAL OBSERVATIONS}

Before presenting visual observations of each glass as it appeared upon cooling, it is fit to explain the terminology used in describing the appearance of the glasses. The terms 'clean' and 'clean with bubbles' as used here mean that there were no undissolved solids visible on the surface of the cooled glass and no visible crystallization. 'Residue' means there was some undissolved chemical left on the surface of the glass. A few pictures are given as examples of clean glasses and glasses with residue. Visual observations of all the quickly cooled glasses are summarized in Table 4.

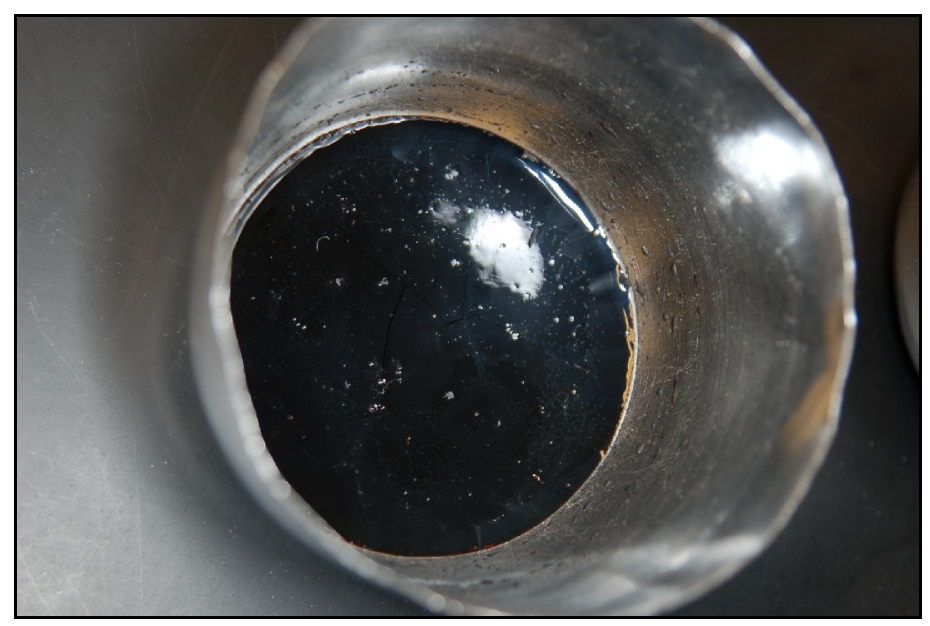

Figure 1. Example of a clean glass, N3-13.

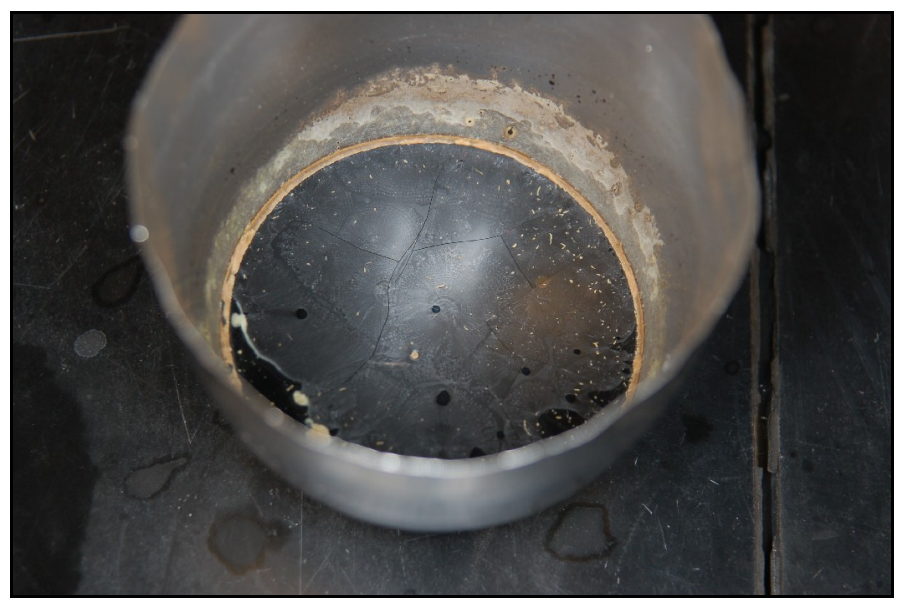

Figure 2. Example of tan residue on glass N3-23. 
Table 4. Visual observations of glasses after cooling in crucibles.

\begin{tabular}{||l|l||}
\hline \hline Glass ID & \\
\hline N3-01 & clean with few bubbles \\
\hline N3-02 & clean with few bubbles \\
\hline N3-03 & ring of tan residue on glass patty extending to edges of crucible \\
\hline N3-04 & residue ring + spots of tan residue in middle of glass patty surface \\
\hline N3-05 & clean \\
\hline N3-06 & bright yellow residue on edges of crucible \\
\hline N3-07 & thick ring of tan residue on patty \\
\hline N3-08 & thick ring of tan residue on patty \\
\hline N3-09 & clean \\
\hline N3-10 & large spots of yellowish residue all over surface \\
\hline N3-11 & large spots of tan residue all over surface \\
\hline N3-12 & large spots of tan residue all over surface \\
\hline N3-13 & clean \\
\hline N3-14 & clean \\
\hline N3-15 & clean \\
\hline N3-16 & clean \\
\hline N3-17 & clean \\
\hline N3-18 & clean \\
\hline N3-19 & clean \\
\hline N3-20 & light residue on edges of crucible \\
\hline N3-21 & yellowish residue on edges on crucible + large splotch of residue on patty \\
\hline N3-22 & clean \\
\hline N3-23 & ring of tan residue on glass patty extending to edges of crucible \\
\hline N3-24 & thick ring of tan residue on patty \\
\hline & \\
\hline
\end{tabular}

Visual observations of glasses N3-01 through N3-12 after the CCC heat treatment were also recorded. None of these glasses showed any evidence of crystallization on any outside surface of the patty. Only three of the glasses exhibited an appearance different than that of their quickly cooled counterparts described in Table 4. Glasses N3-10, N3-11, and N3-12 had a marbled appearance, characteristic of surface crystallization.

\subsection{CHEMICAL COMPOSITION RESULTS}

The chemical composition analyses focused mainly on determining the concentrations of $\mathrm{SO}_{4}{ }^{2-}$ and $\mathrm{MoO}_{3}$ retained in the glasses after melting. This is referred to as retention of these components in the glass, rather than solubility, as it is unlikely that true equilibrium conditions were reached during melting in the crucibles. Table 5 summarizes the target versus measured concentrations of $\mathrm{SO}_{4}{ }^{2-}$ and $\mathrm{MoO}_{3}$ in the study glasses. Note that the measured concentration of $\mathrm{MoO}_{3}$ in glass N3-19 is higher than the target value. This is likely due to a batching error when the glass was prepared.

Some general observations can be made regarding these data for the first twelve glasses (with the second 12 glasses being used to fill in the $\mathrm{SO}_{4}{ }^{2-}$ and $\mathrm{MoO}_{3}$ concentration region of interest):

- Retention of $\mathrm{MoO}_{3}$ in this glass composition reached a maximum of about $3.0 \mathrm{wt} \%$ when no $\mathrm{SO}_{4}{ }^{2-}$ was present.

- Retention of $\mathrm{MoO}_{3}$ was reduced when $\mathrm{SO}_{4}{ }^{2-}$ was added at a target concentration of 0.60 wt $\%$, and was further reduced when $\mathrm{SO}_{4}{ }^{2-}$ was added at a target concentration of $1.20 \mathrm{wt} \%$. 
- Retention of slightly more than $1.0 \mathrm{wt} \% \mathrm{SO}_{4}{ }^{2-}$ without the formation of any visible surface layer was possible in this glass composition when no $\mathrm{MoO}_{3}$ was added (e.g., glass N3-09).

- The amount of $\mathrm{SO}_{4}{ }^{2-}$ retained decreased significantly with increasing target concentrations of $\mathrm{MoO}_{3}$.

Table 5. Target and measured concentrations of $\mathrm{SO}_{4}{ }^{2-}$ and $\mathrm{MoO}_{3}$ in the study glasses.

\begin{tabular}{||c|c|c|c|c||}
\hline \multirow{2}{*}{ Glass ID } & \multicolumn{2}{|c|}{ SO $_{4}{ }^{2-}$ (wt \%) } & \multicolumn{2}{c|}{$\mathbf{M o O}_{\mathbf{3}}$ (wt \%) } \\
\cline { 2 - 5 } & target & measured & target & measured \\
\hline N3-01 & 0.00 & 0.00 & 0.00 & 0.00 \\
\hline N3-02 & 0.00 & 0.00 & 2.00 & 1.96 \\
\hline N3-03 & 0.00 & 0.00 & 4.00 & 3.05 \\
\hline N3-04 & 0.00 & 0.00 & 6.00 & 2.91 \\
\hline N3-05 & 0.60 & 0.582 & 0.00 & 0.00 \\
\hline N3-06 & 0.60 & 0.509 & 2.00 & 1.89 \\
\hline N3-07 & 0.60 & 0.384 & 4.00 & 2.54 \\
\hline N3-08 & 0.60 & 0.300 & 6.00 & 2.79 \\
\hline N3-09 & 1.20 & 1.062 & 0.00 & 0.00 \\
\hline N3-10 & 1.20 & 0.528 & 2.00 & 1.33 \\
\hline N3-11 & 1.20 & 0.410 & 4.00 & 2.05 \\
\hline N3-12 & 1.20 & 0.339 & 6.00 & 2.07 \\
\hline N3-13 & 0.20 & 0.00 & 1.00 & 0.89 \\
\hline N3-14 & 0.40 & 0.357 & 1.00 & 0.92 \\
\hline N3-15 & 0.60 & 0.513 & 1.00 & 0.90 \\
\hline N3-16 & 0.20 & 0.00 & 1.50 & 1.49 \\
\hline N3-17 & 0.40 & 0.361 & 1.50 & 1.37 \\
\hline N3-18 & 0.60 & 0.443 & 1.50 & 1.39 \\
\hline N3-19 & 0.20 & 0.00 & 2.00 & 2.95 \\
\hline N3-20 & 0.40 & 0.374 & 2.00 & 1.98 \\
\hline N3-21 & 0.50 & 0.467 & 2.00 & 2.00 \\
\hline N3-22 & 0.00 & 0.00 & 2.50 & 1.98 \\
\hline N3-23 & 0.00 & 0.00 & 3.00 & 2.76 \\
\hline N3-24 & 0.00 & 0.00 & 3.50 & 2.93 \\
\hline & & & &
\end{tabular}

The complete chemical composition data, including the target and measured concentrations of each element for each of the study glasses, are included in the Appendix. A review of the data indicates little difficulty in meeting the target compositions for each glass. Four of the glasses with the lowest target $\mathrm{SO}_{4}{ }^{2-}$ concentrations (glasses M3-13, N3-14, N3-16 and N3-19 targeted $0.20 \mathrm{wt} \% \mathrm{SO}_{4}{ }^{2-}$ ) had measured $\mathrm{SO}_{4}{ }^{2-}$ concentrations that were below the detection limit of the instrument (indicated as 0.00 in Table 5). Note that the concentrations of $\mathrm{B}_{2} \mathrm{O}_{3}$ and $\mathrm{Li}_{2} \mathrm{O}$ were not measured since, due to the focus on sulfur and molybdenum concentrations, only a lithium metaborate dissolution was used to support the analyses in this study. A small number of discrepancies between the target and measured concentrations of some of the oxides for some of the study glasses are present (e.g., $\mathrm{SiO}_{2}$ concentrations for glasses N3-08 and N3-12, and NiO concentrations for glasses N3-19, N3-20 and N3-21), although these are not expected to affect the outcome of the study.

Wash water samples from the surface of each glass were analyzed by ICP-AES, as summarized in Table 6. These data provide a qualitative measure of the composition of the water soluble surface layer observed on some of the cooled glasses (refer to the descriptions in Table 4). In general, those glasses that showed retention of $\mathrm{SO}_{4}{ }^{2-}$ and $\mathrm{MoO}_{3}$ that was lower than the target concentration had 
high concentrations of these cations on their surfaces after melting. The data also indicate that the alkali, and to some degree, the alkaline earth elements, are present in the surface layer in concentrations proportional to those of the excess sulfur and molybdenum. Note that some of the glasses (e.g., N3-03 and N3-04) had measurable amounts of sulfur in the wash water when no sulfur was batched into the glass. It may be that some sulfur is present as a contaminate in the $\mathrm{MoO} 3$ batch chemical, since MoS2 is the typical industrial source of this oxide.

Table 6. Concentrations of elements measured in the wash water samples.

\begin{tabular}{||c|c|c|c|c|c|c||}
\hline Glass ID & $\mathbf{C a}(\mathbf{m g} / \mathbf{L})$ & $\mathbf{C r}(\mathbf{m g} / \mathbf{L})$ & $\mathbf{L i} \mathbf{( m g / L )}$ & $\mathbf{M o ~ ( m g / L )}$ & $\mathbf{N a ~ ( m g / L ) ~}$ & $\mathbf{S ~ ( m g / L ) ~}$ \\
\hline $\mathrm{N} 3-01$ & 1.92 & 0.13 & 1.45 & $<0.100$ & 17.55 & $<1.00$ \\
\hline N3-02 & 1.95 & 1.18 & 1.50 & 5.78 & 22.17 & $<1.00$ \\
\hline N3-03 & 5.13 & 81.7 & 476 & 8685 & 4103 & 53.3 \\
\hline N3-04 & 37.9 & 85.8 & 1365 & 28000 & 9340 & 134 \\
\hline N3-05 & 0.32 & 0.27 & 1.49 & $<0.100$ & 2.57 & 2.20 \\
\hline N3-06 & 2.34 & 110 & 300 & 4870 & 2980 & 1040 \\
\hline N3-07 & 1.72 & 34.5 & 648 & 11650 & 5415 & 867 \\
\hline N3-08 & 6.34 & 31.3 & 657 & 11600 & 5010 & 647 \\
\hline N3-09 & 0.43 & 0.97 & 1.88 & $<0.100$ & 23.4 & 17.3 \\
\hline N3-10 & 22.7 & 64.3 & 1.46 & 12000 & 13100 & 5195 \\
\hline N3-11 & 36.2 & 30.6 & 1.42 & 12750 & 10850 & 2905 \\
\hline N3-12 & 13.7 & 17.1 & 1.46 & 12000 & 10170 & 2090 \\
\hline N3-13 & $<0.100$ & 1.23 & 2.12 & 15.49 & 17.22 & 7.85 \\
\hline N3-14 & $<0.100$ & 0.45 & 1.62 & 3.50 & 3.88 & 1.55 \\
\hline N3-15 & $<0.100$ & $<0.100$ & 1.56 & 0.87 & 0.69 & $<1.00$ \\
\hline N3-16 & $<0.100$ & 1.03 & 1.61 & 6.60 & 5.49 & $<1.00$ \\
\hline N3-17 & $<0.100$ & 3.66 & 1.95 & 21.67 & 17.16 & 4.33 \\
\hline N3-18 & $<0.100$ & 5.37 & 3.40 & 60.26 & 37.60 & 10.26 \\
\hline N3-19 & 0.704 & 2.96 & 2.06 & 22.3 & 13.7 & 1.27 \\
\hline N3-20 & 1.85 & 16.4 & 19.0 & 422 & 191 & 26.8 \\
\hline N3-21 & 3.34 & 101 & 213 & 4070 & 2140 & 565 \\
\hline N3-22 & 0.61 & 1.42 & 1.67 & 8.68 & 5.09 & $<1.00$ \\
\hline N3-23 & 1.55 & 47.8 & 302 & 7740 & 2790 & 43.6 \\
\hline N3-24 & 6.05 & 95.1 & 734 & 17100 & 6030 & 84.1 \\
\hline \hline
\end{tabular}

\subsection{FITTING OF SULFUR AND MOLYBDENUM RETENTION MODEL}

The tests and observations of the 24 glasses in this study have given some preliminary indications of the combined retention of $\mathrm{SO}_{4}{ }^{2-}$ and $\mathrm{MoO}_{3}$ in this $\mathrm{SB} 6$ - Frit 418 glass system. A preliminary model shown in Figure 3 has been fitted based on visual observations of the cooled glasses. 
SRNL-STI-2009-00569, REVISION 0

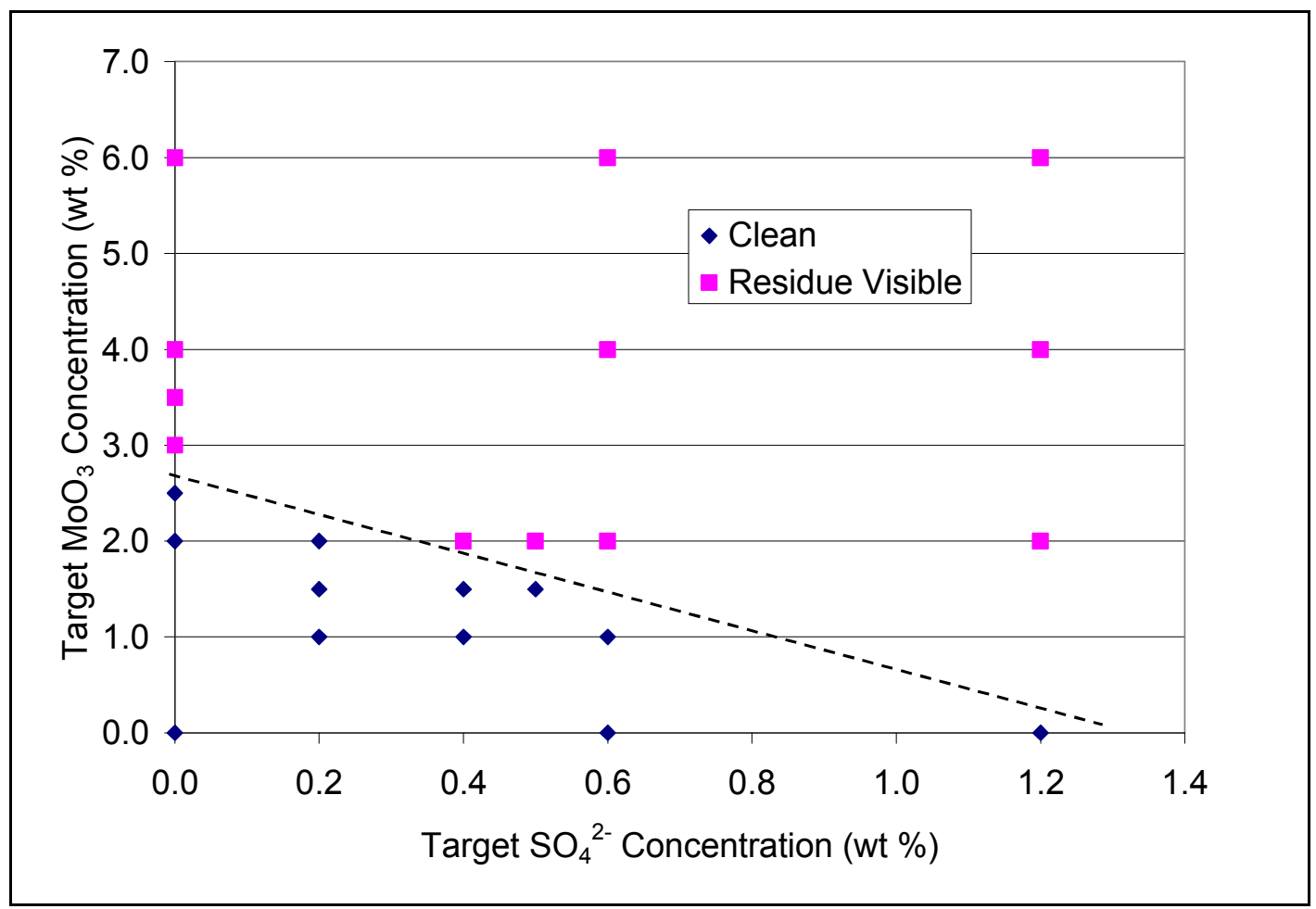

Figure 3. Preliminary model for sulfur and molybdenum retention in the SB6 - Frit 418 glass system studied.

The model is constructed as a line of best fit between the acceptable glasses and the unacceptable glasses, with acceptability being determined using the visual observations. The relationship was assumed to be linear for simplicity. In general, the plot shows a significant decrease in the combined retention of $\mathrm{MoO}_{3}$ and $\mathrm{SO}_{4}{ }^{2-}$ when they are both added to this glass composition. Concentrations of up to $2.5 \mathrm{wt} \% \mathrm{MoO}_{3}$ were retained when no $\mathrm{SO}_{4}{ }^{2-}$ was present, and concentrations of up to $1.2 \mathrm{wt} \%$ $\mathrm{SO}_{4}{ }^{2-}$ were retained when no $\mathrm{MoO}_{3}$ was present. When both components were present, combined retention dropped to, as an example, $1.5 \mathrm{wt} \% \mathrm{MoO}_{3}$ with $0.5 \mathrm{wt} \% \mathrm{SO}_{4}^{2-}$. The acceptable compositions line provides a basis for more testing and future refinement of the model. 


\subsection{SUMMARY}

This study was undertaken to investigate the effect of potentially elevated sulfate and molybdenum concentrations in future nuclear waste glasses. Even low concentrations of $\mathrm{SO}_{4}{ }^{2-}$ and $\mathrm{MoO}_{3}$ that are not incorporated into the glass structure can cause significant problems in a high level waste melter. A matrix of 24 glasses was developed and the glasses were tested for acceptability based on visual observations. A glass was determined to be acceptable for the purposes of this study if it did not have any visible salt residue on its surface. Results from the chemical analysis of the rinse water from each sample were used to confirm the presence or absence of $\mathrm{SO}_{4}{ }^{2-}$ and $\mathrm{MoO}_{3}$ on the surface of glasses as well as other components which might form water soluble compounds with the excess sulfur and molybdenum.

A simple, linear model was developed to show acceptable concentrations of $\mathrm{SO}_{4}{ }^{2-}$ and $\mathrm{MoO}_{3}$ in an example waste glass similar in composition to the SB6 projection used here. This model was constructed for scoping studies only and is not ready for implementation in support of actual waste vitrification. Several other factors must be considered in determining the limits of sulfate and molybdenum concentrations in the waste vitrification process, including but not limited to, impacts on refractory and melter component corrosion, effects on the melter off-gas system, and impacts on the chemical durability and crystallization of the glass product. 


\subsection{REFERENCES}

1. Larsen, D. D. and J. M. Gillam, "Sludge Batch 6 Predicted Batch and Blend Compositions, Post-Aluminum Dissolution," U.S. Department of Energy Report SRR-LWP2009-00006, Revision 0, Savannah River Remediation, LLC, Aiken, SC (2009).

2. Schumacher, R. F., M. E. Smith and J. F. Sproull, "Review of Background Applicable to the Potential for a Steam Explosion in the DWPF Melter," U.S. Department of Energy Report WSRC-RD-91-15, Westinghouse Savannah River Company, Aiken, SC (1991).

3. Bickford, D. F., A. Applewhite-Ramsey, C. M. Jantzen and K. G. Brown, "Control of Radioactive Waste Glass Melters: I, Preliminary General Limits at Savannah River," Journal of the American Ceramic Society, 73 [10] 2896-2902 (1990).

4. Bickford, D. F. and C. M. Jantzen, "Inhibitor Limits for Washed Precipitate Based on Glass Quality and Solubility Limits," U.S. Department of Energy Report DPST-86-546, E.I. DuPont deNemours \& Co., Savannah River Laboratory, Aiken, SC (1986).

5. Peeler, D. K., C. C. Herman, M. E. Smith, T. H. Lorier, D. R. Best, T. B. Edwards and M. A. Baich, "An Assessment of the Sulfate Solubility Limit for the Frit 418 - Sludge Batch 2/3 System," U.S. Department of Energy Report WSRC-TR-2004-00081, Revision 0, Westinghouse Savannah River Company, Aiken, SC (2004).

6. Peeler, D. K., T. B. Edwards and K. M. Fox, "Delaying the SB4 Transfer: An Assessment of the Impact on the Frit Recommendation and the Variability Study," U.S. Department of Energy Report SRNL-PSE-2007-00066, Washington Savannah River Company, Aiken, SC (2007).

7. Short, R. J., R. J. Hand and N. C. Hyatt, "Molybdenum in Nuclear Waste Glasses Incorporation and Redox State," U.S. Department of Energy Report ISL, Department of Engineering Materials, University of Sheffield, (2002).

8. Peeler, D. K., T. B. Edwards and K. M. Fox, "The Impact of Compositional Variation on SB6 Projected Operating Windows," U.S. Department of Energy Report SRNL-L3100-200900029, Savannah River National Laboratory, Aiken, SC (2009).

9. Raszewski, F. C., D. R. Best and D. K. Peeler, "An Assessment of the Applicability of the $0.6 \mathrm{wt} \% \mathrm{SO}_{4}{ }^{2-}$ PCCS Limit for the Frit 418-SB5 System," U.S. Department of Energy Report SRNL-L3100-2008-00023, Savannah River National Laboratory, Aiken, SC (2008).

10. Lorier, T. H., I. A. Reamer and R. J. Workman, "Initial Sulfate Solubility Study for Sludge Batch 4 (SB4)," U.S. Department of Energy Report WSRC-TR-2005-00213, Revision 0, Washington Savannah River Company, Aiken, SC (2005). 
11. Marra, S. L. and C. M. Jantzen, "Characterization of Projected DWPF Glass Heat Treated to Simulate Canister Centerline Cooling," U.S. Department of Energy Report WSRCTR-92-142, Revision 1, Westinghouse Savannah River Company, Aiken, SC (1993). 
APPENDIX A.

Target and Measured Compositions of the Study Glasses

\begin{tabular}{|c|c|c|c|c|}
\hline & \multicolumn{2}{|c|}{ "Glass N3-01 } & \multicolumn{2}{|c|}{ N3-02 } \\
\hline Oxide & Target (wt \%) & Measured (wt \%) & Target (wt \%) & Measured (wt \%) \\
\hline $\mathrm{Al}_{2} \mathrm{O}_{3}$ & 8.28 & 8.08 & 8.11 & 8.14 \\
\hline $\mathrm{B}_{2} \mathrm{O}_{3}$ & 5.30 & not measured & 5.20 & not measured \\
\hline $\mathrm{BaO}$ & 0.06 & 0.046 & 0.06 & 0.078 \\
\hline $\mathrm{CaO}$ & 0.90 & 0.838 & 0.88 & 0.858 \\
\hline $\mathrm{CeO}_{2}$ & 0.05 & 0.056 & 0.05 & 0.048 \\
\hline $\mathrm{Cr}_{2} \mathrm{O}_{3}$ & 0.11 & 0.082 & 0.10 & 0.105 \\
\hline $\mathrm{CuO}$ & 0.03 & 0.031 & 0.03 & 0.036 \\
\hline $\mathrm{Fe}_{2} \mathrm{O}_{3}$ & 8.72 & 8.29 & 8.55 & 7.73 \\
\hline $\mathrm{K}_{2} \mathrm{O}$ & 0.01 & 0.00 & 0.01 & 0.00 \\
\hline $\mathrm{La}_{2} \mathrm{O}_{3}$ & 0.02 & 0.020 & 0.02 & 0.020 \\
\hline $\mathrm{Li}_{2} \mathrm{O}$ & 5.30 & not measured & 5.20 & not measured \\
\hline $\mathrm{MgO}$ & 0.70 & 0.679 & 0.69 & 0.669 \\
\hline $\mathrm{MnO}_{2}$ & 3.10 & 3.09 & 3.04 & 3.11 \\
\hline $\mathrm{MoO}_{3}$ & 0.00 & 0.00 & 1.99 & 1.96 \\
\hline $\mathrm{Na}_{2} \mathrm{O}$ & 14.89 & 14.9 & 14.59 & 15.0 \\
\hline $\mathrm{NiO}$ & 1.39 & 1.35 & 1.36 & 1.31 \\
\hline $\mathrm{PbO}$ & 0.04 & 0.025 & 0.03 & 0.026 \\
\hline $\mathrm{SO}_{4}$ & 0.00 & 0.00 & 0.00 & 0.00 \\
\hline $\mathrm{SiO}_{2}$ & 50.94 & 50.4 & 49.93 & 49.4 \\
\hline $\mathrm{TiO}_{2}$ & 0.01 & 0.00 & 0.01 & 0.00 \\
\hline $\mathrm{ZnO}$ & 0.04 & 0.033 & 0.03 & 0.032 \\
\hline $\mathrm{ZrO}_{2}$ & 0.11 & 0.111 & 0.11 & 0.117 \\
\hline Total & 100.00 & 88.0 & 100.00 & 88.6 \\
\hline
\end{tabular}


SRNL-STI-2009-00569, REVISION 0

\begin{tabular}{|c|c|c|c|c|}
\hline & \multicolumn{2}{|c|}{ "Glass N3-03 } & \multicolumn{2}{|c|}{ N3-04 } \\
\hline Oxide & Target (wt \%) & Measured (wt \%) & Target (wt \%) & Measured (wt \%) \\
\hline $\mathrm{Al}_{2} \mathrm{O}_{3}$ & 7.95 & 7.98 & 7.78 & 7.92 \\
\hline $\mathrm{B}_{2} \mathrm{O}_{3}$ & 5.09 & not measured & 4.99 & not measured \\
\hline $\mathrm{BaO}$ & 0.05 & 0.049 & 0.05 & 0.06 \\
\hline $\mathrm{CaO}$ & 0.86 & 0.832 & 0.84 & 0.89 \\
\hline $\mathrm{CeO}_{2}$ & 0.05 & 0.047 & 0.05 & 0.06 \\
\hline $\mathrm{Cr}_{2} \mathrm{O}_{3}$ & 0.10 & 0.087 & 0.10 & 0.05 \\
\hline $\mathrm{CuO}$ & 0.03 & 0.038 & 0.03 & 0.03 \\
\hline $\mathrm{Fe}_{2} \mathrm{O}_{3}$ & 8.38 & 8.97 & 8.20 & 7.16 \\
\hline $\mathrm{K}_{2} \mathrm{O}$ & 0.01 & 0.00 & 0.01 & 0.00 \\
\hline $\mathrm{La}_{2} \mathrm{O}_{3}$ & 0.02 & 0.018 & 0.02 & 0.02 \\
\hline $\mathrm{Li}_{2} \mathrm{O}$ & 5.09 & not measured & 4.99 & not measured \\
\hline $\mathrm{MgO}$ & 0.68 & 0.659 & 0.66 & 0.672 \\
\hline $\mathrm{MnO}_{2}$ & 2.98 & 3.01 & 2.92 & 2.86 \\
\hline $\mathrm{MoO}_{3}$ & 3.98 & 3.05 & 5.97 & 2.91 \\
\hline $\mathrm{Na}_{2} \mathrm{O}$ & 14.30 & 14.3 & 14.00 & 12.2 \\
\hline $\mathrm{NiO}$ & 1.33 & 1.33 & 1.31 & 1.23 \\
\hline $\mathrm{PbO}$ & 0.03 & 0.029 & 0.03 & 0.028 \\
\hline $\mathrm{SO}_{4}$ & 0.00 & 0.00 & 0.00 & 0.000 \\
\hline $\mathrm{SiO}_{2}$ & 48.91 & 49.2 & 47.90 & 50.9 \\
\hline $\mathrm{TiO}_{2}$ & 0.01 & 0.00 & 0.01 & 0.00 \\
\hline $\mathrm{ZnO}$ & 0.03 & 0.039 & 0.03 & 0.030 \\
\hline $\mathrm{ZrO}_{2}$ & 0.11 & 0.108 & 0.11 & 0.117 \\
\hline Total & 100.00 & 89.7 & 100.00 & 87.2 \\
\hline
\end{tabular}


SRNL-STI-2009-00569, REVISION 0

\begin{tabular}{|c|c|c|c|c|}
\hline & \multicolumn{2}{|c|}{ Glass N3-05 } & \multicolumn{2}{|c|}{ N3-06 } \\
\hline Oxide & Target (wt \%) & Measured (wt \%) & Target (wt \%) & Measured (wt \%) \\
\hline $\mathrm{Al}_{2} \mathrm{O}_{3}$ & 8.23 & 7.92 & 8.06 & 8.08 \\
\hline $\mathrm{B}_{2} \mathrm{O}_{3}$ & 5.27 & not measured & 5.17 & not measured \\
\hline $\mathrm{BaO}$ & 0.06 & 0.082 & 0.06 & 0.055 \\
\hline $\mathrm{CaO}$ & 0.89 & 0.883 & 0.87 & 0.845 \\
\hline $\mathrm{CeO}_{2}$ & 0.05 & 0.049 & 0.05 & 0.047 \\
\hline $\mathrm{Cr}_{2} \mathrm{O}_{3}$ & 0.11 & 0.042 & 0.10 & 0.118 \\
\hline $\mathrm{CuO}$ & 0.03 & 0.043 & 0.03 & 0.039 \\
\hline $\mathrm{Fe}_{2} \mathrm{O}_{3}$ & 8.67 & 8.14 & 8.50 & 9.28 \\
\hline $\mathrm{K}_{2} \mathrm{O}$ & 0.01 & 0.00 & 0.01 & 0.00 \\
\hline $\mathrm{La}_{2} \mathrm{O}_{3}$ & 0.02 & 0.023 & 0.02 & 0.019 \\
\hline $\mathrm{Li}_{2} \mathrm{O}$ & 5.27 & not measured & 5.17 & not measured \\
\hline $\mathrm{MgO}$ & 0.70 & 0.674 & 0.69 & 0.630 \\
\hline $\mathrm{MnO}_{2}$ & 3.08 & 2.89 & 3.02 & 3.00 \\
\hline $\mathrm{MoO}_{3}$ & 0.00 & 0.00 & 1.99 & 1.89 \\
\hline $\mathrm{Na}_{2} \mathrm{O}$ & 14.80 & 13.6 & 14.50 & 14.4 \\
\hline $\mathrm{NiO}$ & 1.38 & 1.22 & 1.35 & 1.31 \\
\hline $\mathrm{PbO}$ & 0.04 & 0.024 & 0.03 & 0.029 \\
\hline $\mathrm{SO}_{4}$ & 0.60 & 0.582 & 0.60 & 0.509 \\
\hline $\mathrm{SiO}_{2}$ & 50.63 & 51.6 & 49.62 & 49.3 \\
\hline $\mathrm{TiO}_{2}$ & 0.01 & 0.00 & 0.01 & 0.00 \\
\hline $\mathrm{ZnO}$ & 0.04 & 0.036 & 0.03 & 0.018 \\
\hline $\mathrm{ZrO}_{2}$ & 0.11 & 0.117 & 0.11 & 0.121 \\
\hline Total & 100.00 & 87.9 & 100.00 & 89.7 \\
\hline
\end{tabular}


SRNL-STI-2009-00569, REVISION 0

\begin{tabular}{|c|c|c|c|c|}
\hline & \multicolumn{2}{|c|}{ "Glass N3-07 } & \multicolumn{2}{|c|}{ N3-08 } \\
\hline Oxide & Target (wt \%) & Measured (wt \%) & Target (wt \%) & Measured (wt \%) \\
\hline $\mathrm{Al}_{2} \mathrm{O}_{3}$ & 7.90 & 8.09 & 7.73 & 8.35 \\
\hline $\mathrm{B}_{2} \mathrm{O}_{3}$ & 5.06 & not measured & 4.96 & not measured \\
\hline $\mathrm{BaO}$ & 0.05 & 0.064 & 0.05 & 0.049 \\
\hline $\mathrm{CaO}$ & 0.86 & 0.830 & 0.84 & 0.840 \\
\hline $\mathrm{CeO}_{2}$ & 0.05 & 0.123 & 0.05 & 0.054 \\
\hline $\mathrm{Cr}_{2} \mathrm{O}_{3}$ & 0.10 & 0.091 & 0.10 & 0.099 \\
\hline $\mathrm{CuO}$ & 0.03 & 0.037 & 0.03 & 0.032 \\
\hline $\mathrm{Fe}_{2} \mathrm{O}_{3}$ & 8.33 & 8.02 & 8.15 & 7.63 \\
\hline $\mathrm{K}_{2} \mathrm{O}$ & 0.01 & 0.00 & 0.01 & 0.00 \\
\hline $\mathrm{La}_{2} \mathrm{O}_{3}$ & 0.02 & 0.029 & 0.02 & 0.021 \\
\hline $\mathrm{Li}_{2} \mathrm{O}$ & 5.06 & not measured & 4.96 & not measured \\
\hline $\mathrm{MgO}$ & 0.67 & 0.653 & 0.66 & 0.663 \\
\hline $\mathrm{MnO}_{2}$ & 2.96 & 2.93 & 2.90 & 3.04 \\
\hline $\mathrm{MoO}_{3}$ & 3.98 & 2.54 & 5.97 & 2.79 \\
\hline $\mathrm{Na}_{2} \mathrm{O}$ & 14.21 & 13.7 & 13.91 & 13.7 \\
\hline $\mathrm{NiO}$ & 1.33 & 1.26 & 1.30 & 1.34 \\
\hline $\mathrm{PbO}$ & 0.03 & 0.033 & 0.03 & 0.028 \\
\hline $\mathrm{SO}_{4}$ & 0.60 & 0.384 & 0.60 & 0.300 \\
\hline $\mathrm{SiO}_{2}$ & 48.61 & 48.2 & 47.59 & 50.3 \\
\hline $\mathrm{TiO}_{2}$ & 0.01 & 0.00 & 0.01 & 0.00 \\
\hline $\mathrm{ZnO}$ & 0.03 & 0.047 & 0.03 & 0.036 \\
\hline $\mathrm{ZrO}_{2}$ & 0.11 & 0.122 & 0.11 & 0.109 \\
\hline Total & 100.00 & 87.2 & 100.00 & 89.4 \\
\hline
\end{tabular}


SRNL-STI-2009-00569, REVISION 0

\begin{tabular}{||c|c|c|c|c||}
\hline & \multicolumn{2}{|c|}{ Glass N3-09 } & \multicolumn{2}{c||}{ N3-10 } \\
\hline Oxide & Target (wt \%) & Measured (wt \%) & Target (wt \%) & Measured (wt \%) \\
\hline $\mathrm{Al}_{2} \mathrm{O}_{3}$ & 8.18 & 8.25 & 8.01 & 8.56 \\
\hline $\mathrm{B}_{2} \mathrm{O}_{3}$ & 5.24 & not measured & 5.14 & not measured \\
\hline $\mathrm{BaO}$ & 0.06 & 0.053 & 0.06 & 0.050 \\
\hline $\mathrm{CaO}$ & 0.89 & 0.867 & 0.87 & 0.876 \\
\hline $\mathrm{CeO}_{2}$ & 0.05 & 0.048 & 0.05 & 0.054 \\
\hline $\mathrm{Cr}_{2} \mathrm{O}_{3}$ & 0.11 & 0.102 & 0.03 & 0.157 \\
\hline $\mathrm{CuO}_{\mathrm{Fe}} \mathrm{O}_{3}$ & 0.03 & 0.035 & 8.45 & 0.035 \\
\hline $\mathrm{K}_{2} \mathrm{O}$ & 8.62 & 7.84 & 0.01 & 8.73 \\
\hline $\mathrm{La}_{2} \mathrm{O}_{3}$ & 0.01 & 0.00 & 0.02 & 0.00 \\
\hline $\mathrm{Li}_{2} \mathrm{O}$ & 0.02 & 0.021 & 5.14 & 0.020 \\
\hline $\mathrm{MgO}$ & 5.24 & not measured & 0.68 & not measured \\
\hline $\mathrm{MnO}_{2}$ & 0.69 & 0.669 & 3.00 & 0.699 \\
\hline $\mathrm{MoO}_{3}$ & 0.00 & 3.04 & 1.99 & 3.19 \\
\hline $\mathrm{Na}_{2} \mathrm{O}$ & 14.71 & 0.00 & 14.42 & 1.33 \\
\hline $\mathrm{NiO}$ & 1.37 & 14.7 & 1.34 & 14.7 \\
\hline $\mathrm{PbO}_{\mathrm{SbO}}$ & 0.04 & 1.33 & 0.03 & 1.38 \\
\hline $\mathrm{SiO}_{4}$ & 1.19 & 0.031 & 1.19 & 0.032 \\
\hline $\mathrm{TiO}_{2}$ & 50.33 & 1.062 & 0.01 & 0.528 \\
\hline $\mathrm{ZnO}_{\mathrm{ZrO}}$ & 0.01 & 49.8 & 0.03 & 51.9 \\
\hline $\mathrm{Total}$ & 0.04 & 0.00 & 100.00 & 0.00 \\
\hline
\end{tabular}


SRNL-STI-2009-00569, REVISION 0

\begin{tabular}{|c|c|c|c|c|}
\hline & \multicolumn{2}{|c|}{ "Glass N3-11 } & \multicolumn{2}{|c|}{ N3-12 } \\
\hline Oxide & Target (wt \%) & Measured (wt \%) & Target (wt \%) & Measured (wt \%) \\
\hline $\mathrm{Al}_{2} \mathrm{O}_{3}$ & 7.85 & 8.65 & 7.68 & 8.60 \\
\hline $\mathrm{B}_{2} \mathrm{O}_{3}$ & 5.03 & not measured & 4.92 & not measured \\
\hline $\mathrm{BaO}$ & 0.05 & 0.046 & 0.05 & 0.037 \\
\hline $\mathrm{CaO}$ & 0.85 & 0.852 & 0.83 & 0.883 \\
\hline $\mathrm{CeO}_{2}$ & 0.05 & 0.051 & 0.05 & 0.050 \\
\hline $\mathrm{Cr}_{2} \mathrm{O}_{3}$ & 0.10 & 0.097 & 0.10 & 0.034 \\
\hline $\mathrm{CuO}$ & 0.03 & 0.033 & 0.03 & 0.036 \\
\hline $\mathrm{Fe}_{2} \mathrm{O}_{3}$ & 8.27 & 9.30 & 8.10 & 7.69 \\
\hline $\mathrm{K}_{2} \mathrm{O}$ & 0.01 & 0.00 & 0.01 & 0.00 \\
\hline $\mathrm{La}_{2} \mathrm{O}_{3}$ & 0.02 & 0.020 & 0.02 & 0.026 \\
\hline $\mathrm{Li}_{2} \mathrm{O}$ & 5.03 & not measured & 4.92 & not measured \\
\hline $\mathrm{MgO}$ & 0.67 & 0.694 & 0.65 & 0.714 \\
\hline $\mathrm{MnO}_{2}$ & 2.94 & 3.12 & 2.88 & 3.11 \\
\hline $\mathrm{MoO}_{3}$ & 3.98 & 2.05 & 5.97 & 2.07 \\
\hline $\mathrm{Na}_{2} \mathrm{O}$ & 14.12 & 13.8 & 13.82 & 12.4 \\
\hline $\mathrm{NiO}$ & 1.32 & 1.36 & 1.29 & 1.33 \\
\hline $\mathrm{PbO}$ & 0.03 & 0.041 & 0.03 & 0.018 \\
\hline $\mathrm{SO}_{4}$ & 1.19 & 0.410 & 1.19 & 0.339 \\
\hline $\mathrm{SiO}_{2}$ & 48.30 & 51.9 & 47.29 & 56.5 \\
\hline $\mathrm{TiO}_{2}$ & 0.01 & 0.00 & 0.01 & 0.00 \\
\hline $\mathrm{ZnO}$ & 0.03 & 0.028 & 0.03 & 0.029 \\
\hline $\mathrm{ZrO}_{2}$ & 0.11 & 0.111 & 0.11 & 0.126 \\
\hline Total & 100.00 & 92.6 & 100.00 & 94.0 \\
\hline
\end{tabular}


SRNL-STI-2009-00569, REVISION 0

\begin{tabular}{|c|c|c|c|c|}
\hline & \multicolumn{2}{|c|}{ Glass N3-13 } & \multicolumn{2}{|c|}{ N3-14 } \\
\hline Oxide & Target (wt \%) & Measured (wt \%) & Target (wt \%) & Measured (wt \%) \\
\hline $\mathrm{Al}_{2} \mathrm{O}_{3}$ & 8.18 & 8.05 & 8.16 & 8.11 \\
\hline $\mathrm{B}_{2} \mathrm{O}_{3}$ & 5.24 & not measured & 5.23 & not measured \\
\hline $\mathrm{BaO}$ & 0.06 & 0.078 & 0.06 & 0.058 \\
\hline $\mathrm{CaO}$ & 0.89 & 0.860 & 0.88 & 0.856 \\
\hline $\mathrm{CeO}_{2}$ & 0.05 & 0.055 & 0.05 & 0.061 \\
\hline $\mathrm{Cr}_{2} \mathrm{O}_{3}$ & 0.11 & 0.104 & 0.11 & 0.142 \\
\hline $\mathrm{CuO}$ & 0.03 & 0.041 & 0.03 & 0.036 \\
\hline $\mathrm{Fe}_{2} \mathrm{O}_{3}$ & 8.62 & 8.94 & 8.60 & 9.07 \\
\hline $\mathrm{K}_{2} \mathrm{O}$ & 0.01 & 0.00 & 0.01 & 0.00 \\
\hline $\mathrm{La}_{2} \mathrm{O}_{3}$ & 0.02 & 0.019 & 0.02 & 0.023 \\
\hline $\mathrm{Li}_{2} \mathrm{O}$ & 5.24 & not measured & 5.23 & not measured \\
\hline $\mathrm{MgO}$ & 0.69 & 0.646 & 0.69 & 0.670 \\
\hline $\mathrm{MnO}_{2}$ & 3.06 & 3.02 & 3.06 & 3.05 \\
\hline $\mathrm{MoO}_{3}$ & 0.99 & 0.89 & 0.99 & 0.92 \\
\hline $\mathrm{Na}_{2} \mathrm{O}$ & 14.71 & 14.6 & 14.68 & 14.5 \\
\hline $\mathrm{NiO}$ & 1.37 & 1.31 & 1.37 & 1.31 \\
\hline $\mathrm{PbO}$ & 0.04 & 0.027 & 0.04 & 0.034 \\
\hline $\mathrm{SO}_{4}$ & 0.20 & 0.00 & 0.40 & 0.357 \\
\hline $\mathrm{SiO}_{2}$ & 50.33 & 49.2 & 50.23 & 49.7 \\
\hline $\mathrm{TiO}_{2}$ & 0.01 & 0.00 & 0.01 & 0.00 \\
\hline $\mathrm{ZnO}$ & 0.04 & 0.035 & 0.04 & 0.033 \\
\hline $\mathrm{ZrO}_{2}$ & 0.11 & 0.111 & 0.11 & 0.114 \\
\hline Total & 100.00 & 88.0 & 100.00 & 89.1 \\
\hline
\end{tabular}


SRNL-STI-2009-00569, REVISION 0

\begin{tabular}{|c|c|c|c|c|}
\hline & \multicolumn{2}{|c|}{ Glass N3-15 } & \multicolumn{2}{|c|}{ N3-16 } \\
\hline Oxide & Target (wt \%) & Measured (wt \%) & Target (wt \%) & Measured (wt \%) \\
\hline $\mathrm{Al}_{2} \mathrm{O}_{3}$ & 8.14 & 8.08 & 8.14 & 8.21 \\
\hline $\mathrm{B}_{2} \mathrm{O}_{3}$ & 5.22 & not measured & 5.21 & not measured \\
\hline $\mathrm{BaO}$ & 0.06 & 0.042 & 0.06 & 0.035 \\
\hline $\mathrm{CaO}$ & 0.88 & 0.886 & 0.88 & 0.846 \\
\hline $\mathrm{CeO}_{2}$ & 0.05 & 0.047 & 0.05 & 0.052 \\
\hline $\mathrm{Cr}_{2} \mathrm{O}_{3}$ & 0.11 & 0.234 & 0.11 & 0.087 \\
\hline $\mathrm{CuO}$ & 0.03 & 0.036 & 0.03 & 0.039 \\
\hline $\mathrm{Fe}_{2} \mathrm{O}_{3}$ & 8.59 & 9.28 & 8.58 & 8.37 \\
\hline $\mathrm{K}_{2} \mathrm{O}$ & 0.01 & 0.00 & 0.01 & 0.00 \\
\hline $\mathrm{La}_{2} \mathrm{O}_{3}$ & 0.02 & 0.019 & 0.02 & 0.021 \\
\hline $\mathrm{Li}_{2} \mathrm{O}$ & 5.22 & not measured & 5.21 & not measured \\
\hline $\mathrm{MgO}$ & 0.69 & 0.650 & 0.69 & 0.678 \\
\hline $\mathrm{MnO}_{2}$ & 3.05 & 2.99 & 3.05 & 3.05 \\
\hline $\mathrm{MoO}_{3}$ & 0.99 & 0.90 & 1.49 & 1.49 \\
\hline $\mathrm{Na}_{2} \mathrm{O}$ & 14.65 & 14.6 & 14.64 & 14.6 \\
\hline $\mathrm{NiO}$ & 1.37 & 1.31 & 1.37 & 1.33 \\
\hline $\mathrm{PbO}$ & 0.04 & 0.023 & 0.04 & 0.036 \\
\hline $\mathrm{SO}_{4}$ & 0.60 & 0.513 & 0.20 & 0.00 \\
\hline $\mathrm{SiO}_{2}$ & 50.13 & 49.5 & 50.08 & 49.9 \\
\hline $\mathrm{TiO}_{2}$ & 0.01 & 0.00 & 0.01 & 0.00 \\
\hline $\mathrm{ZnO}$ & 0.04 & 0.022 & 0.04 & 0.026 \\
\hline $\mathrm{ZrO}_{2}$ & 0.11 & 0.113 & 0.11 & 0.111 \\
\hline Total & 100.00 & 89.2 & 100.00 & 88.9 \\
\hline
\end{tabular}


SRNL-STI-2009-00569, REVISION 0

\begin{tabular}{|c|c|c|c|c||}
\hline & \multicolumn{2}{|c|}{ Glass N3-17 } & \multicolumn{2}{c||}{ N3-18 } \\
\hline Oxide & Target (wt \%) & Measured (wt \%) & Target (wt \%) & Measured (wt \%) \\
\hline $\mathrm{Al}_{2} \mathrm{O}_{3}$ & 8.12 & 7.89 & 8.11 & 7.86 \\
\hline $\mathrm{B}_{2} \mathrm{O}_{3}$ & 5.20 & not measured & 5.20 & not measured \\
\hline $\mathrm{BaO}$ & 0.06 & 0.048 & 0.06 & 0.049 \\
\hline $\mathrm{CaO}$ & 0.88 & 0.835 & 0.05 & 0.822 \\
\hline $\mathrm{CeO}_{2}$ & 0.05 & 0.051 & 0.10 & 0.055 \\
\hline $\mathrm{Cr}_{2} \mathrm{O}_{3}$ & 0.11 & 0.126 & 0.03 & 0.036 \\
\hline $\mathrm{CuO}_{\mathrm{Fe}} \mathrm{O}_{3}$ & 0.03 & 0.034 & 8.55 & 9.90 \\
\hline $\mathrm{K}_{2} \mathrm{O}$ & 8.56 & 9.12 & 0.01 & 0.00 \\
\hline $\mathrm{La}_{2} \mathrm{O}_{3}$ & 0.01 & 0.00 & 0.02 & 0.020 \\
\hline $\mathrm{Li}_{2} \mathrm{O}$ & 0.02 & 0.020 & 5.20 & not measured \\
\hline $\mathrm{MgO}$ & 5.20 & not measured & 0.69 & 0.658 \\
\hline $\mathrm{MnO}_{2}$ & 0.69 & 0.676 & 3.04 & 2.98 \\
\hline $\mathrm{MoO}_{3}$ & 3.04 & 2.98 & 1.49 & 1.37 \\
\hline $\mathrm{Na}_{2} \mathrm{O}$ & 1.49 & 1.39 & 14.59 & 14.2 \\
\hline $\mathrm{NiO}$ & 14.61 & 14.3 & 1.36 & 1.28 \\
\hline $\mathrm{PbO}^{\mathrm{SOO} O}$ & 0.04 & 1.31 & 0.03 & 0.030 \\
\hline $\mathrm{SiO}_{2}$ & 0.40 & 0.033 & 0.50 & 0.443 \\
\hline $\mathrm{TiO}_{2}$ & 0.01 & 0.361 & 0.01 & 48.4 \\
\hline $\mathrm{ZnO}_{\mathrm{ZnO}}$ & 0.04 & 48.5 & 0.03 & 0.00 \\
\hline $\mathrm{Total}$ & 0.11 & 0.027 & 0.03 & 0.109 \\
\hline \hline
\end{tabular}


SRNL-STI-2009-00569, REVISION 0

\begin{tabular}{|c|c|c|c|c|}
\hline & \multicolumn{2}{|c|}{ Glass N3-19 } & \multicolumn{2}{|c|}{ N3-20 } \\
\hline Oxide & Target (wt \%) & Measured (wt \%) & Target (wt \%) & Measured (wt \%) \\
\hline $\mathrm{Al}_{2} \mathrm{O}_{3}$ & 8.09 & 8.57 & 8.08 & 8.27 \\
\hline $\mathrm{B}_{2} \mathrm{O}_{3}$ & 5.19 & not measured & 5.18 & not measured \\
\hline $\mathrm{BaO}$ & 0.06 & 0.044 & 0.06 & 0.058 \\
\hline $\mathrm{CaO}$ & 0.88 & 0.896 & 0.87 & 0.921 \\
\hline $\mathrm{CeO}_{2}$ & 0.05 & 0.050 & 0.05 & 0.056 \\
\hline $\mathrm{Cr}_{2} \mathrm{O}_{3}$ & 0.10 & 0.045 & 0.10 & 0.063 \\
\hline $\mathrm{CuO}$ & 0.03 & 0.058 & 0.03 & 0.052 \\
\hline $\mathrm{Fe}_{2} \mathrm{O}_{3}$ & 8.53 & 7.92 & 8.52 & 7.89 \\
\hline $\mathrm{K}_{2} \mathrm{O}$ & 0.01 & 0.00 & 0.01 & 0.00 \\
\hline $\mathrm{La}_{2} \mathrm{O}_{3}$ & 0.02 & 0.022 & 0.02 & 0.025 \\
\hline $\mathrm{Li}_{2} \mathrm{O}$ & 5.19 & not measured & 5.18 & not measured \\
\hline $\mathrm{MgO}$ & 0.69 & 0.664 & 0.69 & 0.666 \\
\hline $\mathrm{MnO}_{2}$ & 3.03 & 3.15 & 3.03 & 3.08 \\
\hline $\mathrm{MoO}_{3}$ & 1.99 & 2.95 & 1.99 & 1.98 \\
\hline $\mathrm{Na}_{2} \mathrm{O}$ & 14.56 & 14.8 & 14.53 & 14.6 \\
\hline $\mathrm{NiO}$ & 1.36 & 0.00 & 1.36 & 0.00 \\
\hline $\mathrm{PbO}$ & 0.03 & 0.031 & 0.03 & 0.033 \\
\hline $\mathrm{SO}_{4}$ & 0.20 & 0.00 & 0.40 & 0.374 \\
\hline $\mathrm{SiO}_{2}$ & 49.82 & 51.8 & 49.72 & 51.5 \\
\hline $\mathrm{TiO}_{2}$ & 0.01 & 0.017 & 0.01 & 0.016 \\
\hline $\mathrm{ZnO}$ & 0.03 & 0.032 & 0.03 & 0.038 \\
\hline $\mathrm{ZrO}_{2}$ & 0.11 & 0.112 & 0.11 & 0.110 \\
\hline Total & 100.00 & 91.2 & 100.00 & 89.8 \\
\hline
\end{tabular}


SRNL-STI-2009-00569, REVISION 0

\begin{tabular}{|c|c|c|c|c|}
\hline & \multicolumn{2}{|c|}{ Glass N3-21 } & \multicolumn{2}{|c|}{ N3-22 } \\
\hline Oxide & Target (wt \%) & Measured (wt \%) & Target (wt \%) & Measured (wt \%) \\
\hline$\overline{\mathrm{Al}_{2} \mathrm{O}_{3}}$ & 8.07 & 8.54 & 8.07 & 8.41 \\
\hline $\mathrm{B}_{2} \mathrm{O}_{3}$ & 5.17 & not measured & 5.17 & not measured \\
\hline $\mathrm{BaO}$ & 0.06 & 0.037 & 0.06 & 0.046 \\
\hline $\mathrm{CaO}$ & 0.87 & 0.930 & 0.87 & 0.889 \\
\hline $\mathrm{CeO}_{2}$ & 0.05 & 0.051 & 0.05 & 0.048 \\
\hline $\mathrm{Cr}_{2} \mathrm{O}_{3}$ & 0.10 & 0.050 & 0.10 & 0.054 \\
\hline $\mathrm{CuO}$ & 0.03 & 0.057 & 0.03 & 0.052 \\
\hline $\mathrm{Fe}_{2} \mathrm{O}_{3}$ & 8.51 & 7.66 & 8.51 & 7.65 \\
\hline $\mathrm{K}_{2} \mathrm{O}$ & 0.01 & 0.00 & 0.01 & 0.00 \\
\hline $\mathrm{La}_{2} \mathrm{O}_{3}$ & 0.02 & 0.023 & 0.02 & 0.021 \\
\hline $\mathrm{Li}_{2} \mathrm{O}$ & 5.17 & not measured & 5.17 & not measured \\
\hline $\mathrm{MgO}$ & 0.69 & 0.665 & 0.69 & 0.658 \\
\hline$\overline{\mathrm{MnO}_{2}}$ & 3.02 & 3.14 & 3.02 & 3.10 \\
\hline $\mathrm{MoO}_{3}$ & 1.99 & 1.98 & 2.49 & 2.00 \\
\hline $\mathrm{Na}_{2} \mathrm{O}$ & 14.52 & 15.2 & 14.52 & 15.2 \\
\hline $\mathrm{NiO}$ & 1.35 & 0.00 & 1.35 & 1.32 \\
\hline$\overline{\mathrm{PbO}}$ & 0.03 & 0.026 & 0.03 & 0.028 \\
\hline $\mathrm{SO}_{4}$ & 0.50 & 0.467 & 0.00 & 0.00 \\
\hline $\mathrm{SiO}_{2}$ & 49.67 & 52.1 & 49.67 & 50.8 \\
\hline $\mathrm{TiO}_{2}$ & 0.01 & 0.024 & 0.01 & 0.017 \\
\hline $\mathrm{ZnO}$ & 0.03 & 0.041 & 0.03 & 0.026 \\
\hline $\mathrm{ZrO}_{2}$ & 0.11 & 0.115 & 0.11 & 0.106 \\
\hline Total & 100.00 & 91.1 & 100.00 & 90.4 \\
\hline
\end{tabular}


SRNL-STI-2009-00569, REVISION 0

\begin{tabular}{||c|c|c|c|c||}
\hline & \multicolumn{2}{|c|}{ Glass N3-23 } & \multicolumn{2}{c||}{ N3-24 } \\
\hline Oxide & Target (wt \%) & Measured (wt \%) & Target (wt \%) & Measured (wt \%) \\
\hline $\mathrm{Al}_{2} \mathrm{O}_{3}$ & 8.03 & 8.38 & 7.99 & 8.53 \\
\hline $\mathrm{B}_{2} \mathrm{O}_{3}$ & 5.15 & not measured & 5.12 & not measured \\
\hline $\mathrm{BaO}$ & 0.06 & 0.065 & 0.06 & 0.071 \\
\hline $\mathrm{CaO}$ & 0.87 & 0.882 & 0.86 & 0.879 \\
\hline $\mathrm{CeO}_{2}$ & 0.05 & 0.045 & 0.10 & 0.047 \\
\hline $\mathrm{Cr}_{2} \mathrm{O}_{3}$ & 0.10 & 0.057 & 0.03 & 0.044 \\
\hline $\mathrm{CuO}_{\mathrm{Fe}} \mathrm{O}_{3}$ & 0.03 & 0.057 & 8.42 & 7.56 \\
\hline $\mathrm{K}_{2} \mathrm{O}$ & 8.46 & 8.25 & 0.01 & 0.00 \\
\hline $\mathrm{La}_{2} \mathrm{O}_{3}$ & 0.01 & 0.00 & 0.02 & 0.021 \\
\hline $\mathrm{Li}_{2} \mathrm{O}$ & 0.02 & 0.019 & 5.12 & not measured \\
\hline $\mathrm{MgO}$ & 5.15 & not measured & 0.68 & 0.654 \\
\hline $\mathrm{MnO}_{2}$ & 0.68 & 0.646 & 2.99 & 3.08 \\
\hline $\mathrm{MoO}_{3}$ & 3.01 & 3.05 & 3.48 & 2.93 \\
\hline $\mathrm{Na}_{2} \mathrm{O}$ & 2.98 & 2.76 & 14.37 & 14.9 \\
\hline $\mathrm{NiO}$ & 14.44 & 15.1 & 1.34 & 1.33 \\
\hline $\mathrm{PbO}^{\mathrm{SOO}}$ & 1.35 & 1.33 & 0.03 & 0.028 \\
\hline $\mathrm{SiO}_{2}$ & 0.03 & 0.028 & 0.00 & 0.00 \\
\hline $\mathrm{TiO}_{2}$ & 0.00 & 0.00 & 49.17 & 51.4 \\
\hline $\mathrm{ZnO}_{\mathrm{ZrO}}$ & 0.01 & 50.4 & 0.01 & 0.00 \\
\hline $\mathrm{Total}$ & 0.03 & 0.00 & 0.03 & 0.035 \\
\hline \hline
\end{tabular}




\section{Distribution:}

S. L. Marra, 773-A

A. B. Barnes, 999-W

D. A. Crowley, 773-43A

S. D. Fink, 773-A

C. W. Gardner, 773-A

B. J. Giddings, 786-5A

C. C. Herman, 999-W

F. M. Pennebaker, 773-42A

C. J. Bannochie, 773-42A

D. K. Peeler, 999-W

M. E. Stone, 999-W

K. M. Fox, , 999-W

F.C. Raszewski, 999-W

A.L. Billings, 999-W

J.C. Marra, 773-42A

A.S. Choi, 999-W

D.H. Miller, 999-W 